\title{
Smoothelin-a is essential for functional intestinal smooth muscle contractility in mice
}

Citation for published version (APA):

Niessen, P. M. G., Rensen, S. S. M., Deursen, J., de Man, J., de Laet, A., Vanderwinden, J. M., Wedel, T., Baker, D., Doevendans, P. A. F. M., Hofker, M. H., Gijbels, M. J. J., \& van Eys, G. J. J. M. (2005). Smoothelin-a is essential for functional intestinal smooth muscle contractility in mice. Gastroenterology, 129(5), 1592-1601. https://doi.org/10.1053/j.gastro.2005.08.018

Document status and date:

Published: 01/01/2005

DOI:

10.1053/j.gastro.2005.08.018

Document Version:

Publisher's PDF, also known as Version of record

Document license:

Taverne

Please check the document version of this publication:

- A submitted manuscript is the version of the article upon submission and before peer-review. There can be important differences between the submitted version and the official published version of record.

People interested in the research are advised to contact the author for the final version of the publication, or visit the DOI to the publisher's website.

- The final author version and the galley proof are versions of the publication after peer review.

- The final published version features the final layout of the paper including the volume, issue and page numbers.

Link to publication

\footnotetext{
General rights rights.

- You may freely distribute the URL identifying the publication in the public portal. please follow below link for the End User Agreement:

www.umlib.nl/taverne-license

Take down policy

If you believe that this document breaches copyright please contact us at:

repository@maastrichtuniversity.nl

providing details and we will investigate your claim.
}

Copyright and moral rights for the publications made accessible in the public portal are retained by the authors and/or other copyright owners and it is a condition of accessing publications that users recognise and abide by the legal requirements associated with these

- Users may download and print one copy of any publication from the public portal for the purpose of private study or research.

- You may not further distribute the material or use it for any profit-making activity or commercial gain

If the publication is distributed under the terms of Article $25 \mathrm{fa}$ of the Dutch Copyright Act, indicated by the "Taverne" license above, 


\title{
Smoothelin-A Is Essential for Functional Intestinal Smooth Muscle Contractility in Mice
}

\author{
PETRA NIESSEN,* SANDER RENSEN,* JAN VAN DEURSEN, ${ }^{*}$ JORIS DE MAN, ${ }^{\S}$ ANN DE LAET," \\ JEAN-MARIE VANDERWINDEN, ${ }^{\Uparrow}$ THILO WEDEL," DARREN BAKER, ${ }^{\ddagger}$ PIETER DOEVENDANS, $* *$ \\ MARTEN HOFKER, $*$, ${ }^{*}$ MARION GIJBELS,* and GUILLAUME VAN EYS* \\ *Department of Genetics and Cell Biology, and ${ }^{* \dagger}$ Department of Pathology, Cardiovascular Institute Maastricht, University of Maastricht, \\ Maastricht, The Netherlands; ${ }^{\dagger}$ Department of Pediatrics and Adolescent Medicine, Mayo Clinic, Rochester, Minnesota; ${ }^{\S}$ Laboratory of \\ Gastroenterology, "Laboratory of Cell Biology and Histology and Laboratory of Electrobiology, University of Antwerp, Antwerp, Belgium; \\ "Laboratory of Neurophysiology, Université Libre de Bruxelles, Brussels, Belgium; "Institute of Anatomy, University of Luebeck, Luebeck, \\ Germany; and $* *$ Utrecht Medical Center, the Interuniversity Cardiology Institute of The Netherlands, University of Utrecht, Utrecht, The \\ Netherlands
}

Background \& Aims: In patients with chronic intestinal pseudo-obstruction, intestinal motility is disturbed by either nervous or myogenic aberrations. The cause of the myogenic form is unknown, but it is likely to originate in the contractile apparatus of the smooth muscle cells. Smoothelins are actin-binding proteins that are expressed abundantly in visceral (smoothelin-A) and vascular (smoothelin-B) smooth muscle. Experimental data indicate a role for smoothelins in smooth muscle contraction. A smoothelin-deficient mouse model may help to establish the role of smoothelin-A in intestinal contraction and provide a model for myogenic chronic intestinal pseudo-obstruction. Methods: We used gene targeting to investigate the function of smoothelin-A in intestinal tissues. By deletion of exons 18, 19, and 20 from the smoothelin gene, the expression of both smoothelin isoforms was disrupted. The effects of the deficiency were evaluated by pathologic and physiologic analyses. Results: In smoothelin-A/B knockout mice, the intestine was fragile and less flexible compared with wild-type littermates. The circular and longitudinal muscle layers of the intestine were hypertrophic. Deficiency of smoothelin-A led to irregular slow wave patterns and impaired contraction of intestinal smooth muscle, leading to hampered transport in vivo. This caused obstructions that provoked intestinal diverticulosis and occasionally intestinal rupture. Conclusions: Smoothelin-A is essential for functional contractility of intestinal smooth muscle. Hampered intestinal transit in smoothelin-A/B knockout mice causes obstruction, starvation, and, ultimately, premature death. The pathology of mice lacking smoothelin-A is reminiscent of that seen in patients with chronic intestinal pseudo-obstruction.

7 he principal function of smooth muscle cells (SMCs) in the intestinal tract is to enable propulsion and mixing of food, ${ }^{1}$ which improves the digestion of complex molecules and the absorption of nutrients. Coordi- nated contractions of the circular and longitudinal smooth muscle layers are responsible for peristalsis of the gastrointestinal tract. Contractions of SMCs are slower than those of skeletal and cardiac myocytes, but are more sustained. Hence, the composition of the contractile apparatus of SMCs differs from that of the striated muscle cells. In both cell types, actin-myosin interactions are at the basis of contraction. The contraction of striated muscle is well understood and accessory proteins, such as troponins, are known to be part of the organization of the contractile apparatus and determine the mode of contraction. ${ }^{2,3}$ The architecture and composition of contractile elements in SMCs, however, still is not understood fully. The contractile apparatus of SMCs is connected with the cytoskeleton via dense bodies. It consists of an actinmyosin axis complemented with structural muscle proteins, including $\alpha$-actinin and tropomyosin, and more smooth muscle-specific proteins such as calponin, caldesmon, and smoothelin. ${ }^{4,5}$

Based on their expression pattern, smoothelins have been described as proteins specific for fully differentiated smooth muscle. The 2 major isoforms are smoothelin-A in visceral tissues such as the digestive tract, bladder, and prostate, and smoothelin-B in vascular tissues. ${ }^{6,7}$ Both are found only in actively contracting smooth muscle tissues. Under pathologic conditions with impaired function of smooth muscle, such as aneurysms and restenosis, expression of smoothelins rapidly decreases. ${ }^{8,9}$ In cultured SMCs, smoothelins colocalize with smooth muscle $\alpha$-actin ( $\alpha$-SMA) stress fibers. ${ }^{8,10}$ Recently, we

\footnotetext{
Abbreviations used in this paper: $\alpha$-SMA, smooth muscle $\alpha$-actin; CIP, chronic intestinal pseudo-obstruction; ICC, interstitial cell of Cajal; SMC, smooth muscle cell; Smtn, smoothelin gene.

(C) 2005 by the American Gastroenterological Association 0016-5085/05/ $\$ 30.00$ doi:10.1053/j.gastro.2005.08.018
} 
showed in vitro that smoothelins can bind physically to $\alpha$-SMA under normal physiologic conditions. ${ }^{11}$ These findings point toward a direct role of smoothelin in contraction.

If SMCs are brought into culture, smoothelin expression is down-regulated rapidly, ${ }^{6,10}$ concomitant with their modulation toward a synthetic phenotype. This hampers in vitro investigations of the function of smoothelin in smooth muscle contraction. Therefore, assessment of the function of smoothelins in intestinal contractility requires an in vivo approach. Here, we report the interruption of the smoothelin gene in mice, leading to elimination of both smoothelin-A and smoothelin-B. The smoothelin knockout mice $\left(S m t n-A / B^{-1-}\right)$ show dysfunction of intestinal motility and contractility and die prematurely. The observed phenotype displays pathologies reminiscent of intestinal diverticulosis, chronic intestinal pseudo-obstruction (CIP), and hollow visceral myopathy in humans.

\section{Materials and Methods}

\section{Generation of Smtn-A/B-/- and Smtn-B ${ }^{-/-}$ Mice}

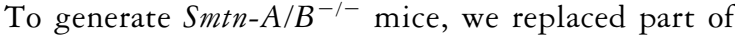
exon 18 and exon 19-20 with a neomycin resistance gene under the control of the thymidine kinase promoter in reverse orientation (Figure $1 A$ ). The targeting vector contained the thymidine kinase gene for negative selection. After electroporation of the PvuII-linearized construct into mouse L129/Sv embryonic stem cells, we selected neomycin-resistant clones with G418 (Invitrogen, Carlsbad, CA) and 1-[2-deoxy $] 2$-fluoro- $\beta$-D-arabinofurasonyl (Invitrogen). DNA from resistant clones was screened by Southern blotting after $P s t$ I restriction digestion, using the $3^{\prime}$ probe indicated in Figure $1 \mathrm{~A}$. Embryonic stem cells from 2 independent targeted clones were injected into $\mathrm{C} 57 \mathrm{Bl} / 6$ blastocysts and implanted into pseudopregnant $\mathrm{C} 57 \mathrm{Bl} / 6$ females. Mating of the resulting chimeric males to $\mathrm{C} 57 \mathrm{Bl} / 6$ females led to germline transmission of the targeted allele as detected by Southern blotting (Figure $1 B$ ). Because the mice had a mixed background (L129/Sv and C57Bl/6), we used littermates as controls. In the food transit experiment we used age- and sex-matched controls. The generation of smoothelin-B knockout mice ( $\left(\mathrm{m} m \mathrm{tn}-\mathrm{B}^{-/-}\right)$is described elsewhere (Rensen et al, unpublished data). In these mice, exons 3-6 of the smoothelin gene are removed and smoothelin-B synthesis is absent; however, smoothelin-A synthesis is not affected. All animal studies were performed according to protocols approved by the Committee on Animal Experimentation of the University of Maastricht.

\section{Reverse-Transcription Polymerase Chain Reaction}

Total RNA was extracted from various tissues with Tri reagent (Sigma-Aldrich, Zwijndrecht, The Netherlands). Reverse transcription was performed using $1 \mu \mathrm{g}$ of RNA in the RevertAid First-Strand complementary DNA synthesis kit (Fermentas, St. Leon-Rot, Germany). Expression of smoothelin messenger RNA in $\operatorname{Smtn}-A / B^{-1-}$ mice was investigated by reverse-transcription polymerase chain reaction using smoothelin-B-specific primers 1F 5'-CCAGGGGGCAGTATGAAGAC-3' and 1R 5'-CGCAGGTGGTTGTAGAGCGA-3' and common smoothelin primers 2F 5'-GAGGAGCGCAAGCTGATCA-3' and 2R 5'-CTGCTGGTGCTGAGAAGGGT-3'. Reverse-transcription polymerase chain reaction products were cloned and sequenced.

\section{Western Blot}

Intestinal tissue homogenates $(n=5)$ were prepared in buffer $(.25 \mathrm{~mol} / \mathrm{L}$ sucrose, $.01 \mathrm{~mol} / \mathrm{L}$ Tris- $\mathrm{HCl} \mathrm{pH} 7.4,2$ $\mathrm{mmol} / \mathrm{L}$ ethylenediaminetetraacetic acid) supplemented with 1 $\mathrm{mmol} / \mathrm{L}$ phenylmethylsulfonyl fluoride. Protein concentration was measured with the BCA Protein Assay Kit (Pierce, Rockford, IL) and $15 \mu \mathrm{g}$ was loaded onto a $9 \%$ sodium dodecyl sulfate-polyacrylamide gel electrophoresis gel. Proteins were blotted on a polyvinylidene difluoride membrane (Hybond-P; Amersham Biosciences, Roosendaal, The Netherlands) and blocked overnight in phosphate-buffered saline containing $.2 \%$ Tween-20 and 5\% Marvel at $4^{\circ} \mathrm{C} . \alpha$-SMA was detected using the monoclonal antibody 1 A 4 (DAKO, Glostrup, Denmark) and a secondary rabbit anti-mouse antibody conjugated with horseradish peroxidase (DAKO). Smooth muscle myosin heavy chain was detected with the rabbit polyclonal immunoglobulin G bt-562 (Campro Scientific, Veenendaal, The Netherlands) followed by donkey-anti-rabbit horseradish peroxidase (Jackson ImmunoResearch Laboratories, Inc., West Grove, PA). Bands were visualized by enhanced chemiluminescence. Subsequently, signals were digitized and analyzed with Quantity One software (Bio-Rad Laboratories, Hercules, CA).

\section{Histology, Immunohistochemistry, and Electron Microscopy}

Organs from mice aged from 0 days to 6 months were fixed overnight in $3.7 \%$ formaldehyde in phosphate-buffered saline, embedded in paraffin, sectioned, and stained with H\&E. Sirius Red staining was performed for the detection of collagen.

Samples of intestine (and several other tissues) were snap-frozen in liquid nitrogen-precooled isopentane and embedded in OCT Tissue Tek compound (Sakura, Chicago, IL). Cryostat sections were stained with biotinylated mouse monoclonal R4A specific for smoothelin. ${ }^{12}$ The ABC-peroxidase kit (Vector Laboratories, Inc, Burlingame, CA) was used for detection, followed by diaminobenzidine tetrahydrochloride staining and hematoxylin counterstaining. Interstitial cells of Cajal (ICCs) were identified by antibody against c-kit (Santa Cruz Biotechnology, Inc., Santa Cruz, CA). ${ }^{13}$ 
A
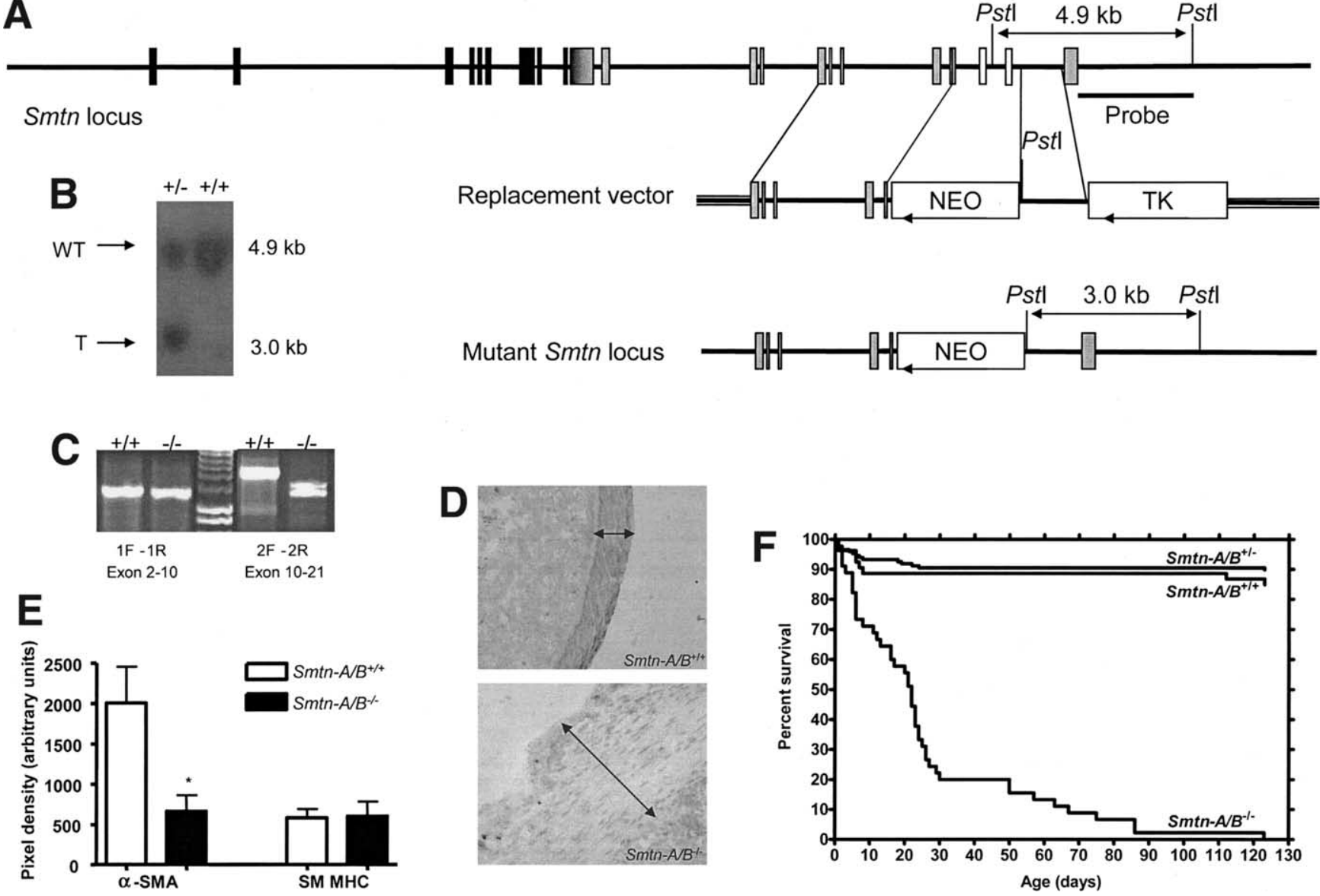

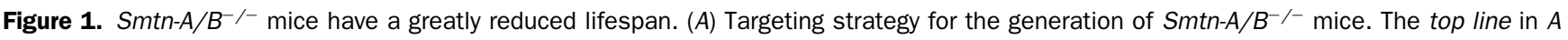
shows the structure of the Smtn gene. $\mathbf{\square}$, smoothelin-B exons; $\square$, exons common to smoothelin-A and smoothelin-B; $\square$, targeted exons. The middle line in $A$ shows the Smtn-A/B $B^{-/-}$targeting vector containing neomycin resistance (NEO) and herpes simplex virus thymidine kinase (TK) genes, both transcribed in the reverse direction to that of the Smtn gene, as indicated by arrows. The bottom line shows the structure of the targeted Smtn allele. The distance between the Pstl sites in the wild-type (top) and mutant (bottom) locus, and the location of the probe used in Southern blot analyses after Pstl digestion, is shown. (B) Southern blot analyses of genomic DNA from wild-type and targeted embryonic stem cells after Pstl digestion with the probe indicated in A. The wild-type Pstl fragment (WT) has a size of $4.9 \mathrm{~kb}$, whereas the mutant Pstl fragment $(\mathrm{T})$ is $3.0 \mathrm{~kb} .(C)$ Reverse-transcription polymerase chain reaction analysis of RNA isolated from the colon shows that $S m t n-A / B^{-1-}$ mice express shorter smoothelin transcripts with exons 16 or 17 spliced to exon 21 (see Methods section for details). (D) Immunohistochemical stainings of jejunum show the loss of smoothelin expression in Smtn-A/B $B^{-/-}$mice. The double-headed arrows indicate the thickness of the muscle layers (see also Figure 4). (E) $\alpha$-SMA concentration is significantly lower in Smtn-A/B-/- mice, whereas smooth muscle myosin heavy chain concentration does not differ $(n=5)$. (F) Kaplan-Meier survival curve of Smtn- $A / B^{+/+}$, Smtn- $A / B^{+/-}$, and Smtn-A/B ${ }^{-/-}$mice showing that $50 \%$ of Smtn-A/B $B^{-/-}$mice die within 3 weeks after birth $(\mathrm{n}=263)$.

Full-thickness biopsy specimens from ileum were obtained from a patient with CIP. Age-matched control specimens were obtained from patients with diseases unrelated to gastrointestinal motility disorders. The use of human tissues was approved by the Medical Institutional Ethics Committee of the Faculty of Medicine, University of Luebeck, Germany. Tissues were processed as described by Vanderwinden et al. ${ }^{14}$

For electron microscopy, tissues were fixed in $3 \%$ phosphatebuffered glutaraldehyde for 24 hours and postfixed for 1 hour in $1 \%$ osmium tetroxide. Tissues then were dehydrated through a graded ethanol series and routinely embedded in Epon (SPI Supplies, West Chester, PA). Ultrathin sections were counterstained with uranyl acetate and lead citrate and examined in a Philips CM100 electron microscope (Philips, Eindhoven, The Netherlands).

\section{Whole-Gut Transit Time Test}

To determine the intestinal function, a whole-gut transit time test was used as previously described. ${ }^{15} \mathrm{We}$ injected $100 \mu \mathrm{L}$ of $6 \%$ carmine (Sigma-Aldrich C1022) in phosphate-buffered saline $(\mathrm{pH}$ 7.0) into the stomachs of 6 $S m t n-A / B^{+/+}, S m t n-A / B^{+/-}$, and $S m t n-A / B^{-1-}$, and 5 Smtn$B^{+/+}$and $S m t n-B^{-/-}$mice, and monitored their feces for the first appearance of red dye.

\section{Contrast Radiography}

After sedation with $.15 \mu \mathrm{L}$ Nembutal (Ceva Sante Animale BV, Maassluis, The Netherlands) by intraperitoneal injection, $.3 \mathrm{~mL}$ of barium sulfate suspension (polibar $1 \mathrm{~g} / \mathrm{mL}$, E-Z-EM Inc, Lake Success, NY; diluted 1:4 with water) was 
injected into the stomachs of $25 m+n-A / B^{-1-}$ and $2 S m t n-A /$ $B^{+/+}$mice (12 weeks old). Progression through the gastrointestinal tract was followed by continuous radiographic examination $(60 \mathrm{kV}, 1.6 \mathrm{~mA})$. Digital radiographic images were taken every 10 minutes with a Philips Diagnost 1997 device (Philips Medical Systems, Best, The Netherlands).

\section{Intestinal Contractility}

Intestinal contractility was studied on 4-6-weekold mice ( $\mathrm{n}=6$ for each group). Before anesthetizing mice with diethyl ether, we fasted them for 24 hours with free access to water. The small intestine of $S m t n-A / B^{-1-}$ and $S m t n-A / B^{+1+}$ littermates (and of $S m t n-B^{-1-}$ and $S m t n-B^{+1+}$ littermates) was removed and put in ice-cold aerated KrebsRinger solution. A $10-\mathrm{cm}$ segment of the jejunum was opened along the longitudinal axis and the mucosa was removed. Longitudinal muscle strips of $6.0 \mathrm{~mm}$ of the jejunum were mounted in organ baths $(5 \mathrm{~mL})$ filled with Krebs-Ringer solution, maintained at $37^{\circ} \mathrm{C}$, and aerated with a mixture of $5 \% \mathrm{CO}_{2}$ and $95 \% \mathrm{O}_{2}$. The muscle strips were positioned between 2 platinum ring electrodes (distance, $10 \mathrm{~mm}$; diameter of rings, $3 \mathrm{~mm}$ ) that were mounted on a Plexiglas (or Perspex) rod. The lower end of the muscle strip was fixed and the other end of the muscle strip was connected to a strain gauge transducer (Scaime, Annemasse, France) for continuous recording of isometric tension. After an equilibration period of 30 minutes during which the strips were washed every 5 minutes, the muscle strips were contracted with $.1 \mu \mathrm{mol} / \mathrm{L}$ carbachol. After washout of carbachol, the strips were stretched (increments of $5 \mathrm{mN}$ ). After stabilization of the basal tone, muscle strips again were contracted with $.1 \mu \mathrm{mol} / \mathrm{L}$ carbachol. This procedure was repeated until the contraction to $.1 \mu \mathrm{mol} / \mathrm{L}$ carbachol was maximal. This point was taken as the point of the optimal length-tension relation. ${ }^{16}$ Muscle strips then were allowed to equilibrate for 60 minutes before starting the experiment. During the equilibration period, the muscle strips were washed every 15 minutes with Krebs-Ringer solution. The contractile effect of electrical field stimulation $(.5-8 \mathrm{~Hz}, 40 \mathrm{~V}$, pulse width, $1 \mathrm{~ms}$; pulse train, $10 \mathrm{~s}$ ), enteric nerves, carbachol $(1 \mathrm{nmol} / \mathrm{L}$ to $1 \mu \mathrm{mol} / \mathrm{L})$, prostaglandin $\mathrm{F} 2 \alpha(1 \mathrm{nmol} / \mathrm{L}$ to $10 \mu \mathrm{mol} / \mathrm{L})$, substance-P (.1-100 $\mathrm{nmol} / \mathrm{L})$, serotonin $(1 \mathrm{nmol} / \mathrm{L}$ to $10 \mu \mathrm{mol} / \mathrm{L})$, and $\mathrm{KCl}(50$ $\mathrm{mmol} / \mathrm{L}$ ) was investigated. To block inhibitory responses to nitric oxide, contractions were studied in the presence of L-nitroarginine, a blocker of nitric oxide synthase. An adjacent jejunal segment was fixed in $4 \%$ formaldehyde for histologic examination and determination of the cross-sectional area. Contractions were normalized to the crosssectional area of the longitudinal jejunal muscle layer.

\section{Intracellular Recordings}

A standard microelectrode technique was used to record slow waves from the SMCs of the small intestine. Pieces of duodenum ( $2 \mathrm{~cm}$ beyond the pyloric sphincter) from the same mice as used for the intestinal contractility studies were used. The segments were opened along the mesenteric border and the mucosa and submucosa were removed. A muscle strip $(15 \times 6 \mathrm{~mm})$ then was pinned, serosal side down, to the Sylgard floor (Dow Corning Europe, La Hulper, Belgium) of a recording chamber that was placed on the stage of an inverted microscope (Diaphot; Nikon, Tokyo, Japan). The tissue was superfused continuously $\left(10 \mathrm{~mL} / \mathrm{min}\right.$; temperature, $36.5^{\circ} \mathrm{C}$ $37^{\circ} \mathrm{C}$ ) with oxygenated Krebs-Ringer solution.

Throughout the experiment, the L-type $\mathrm{Ca}^{2+}$ blocker nicardipine (1 $\mu \mathrm{mol} / \mathrm{L})$ (Sigma Chemical, St. Louis, MO) was present in the superfusion solution to reduce contraction of the intestinal smooth muscle. ${ }^{17,18}$ Intracellular recordings of the SMCs were made with borosilicate glass microelectrodes (1-mm outer diameter; Clarc Electromedical Instruments, Reading, UK) pulled on a P-97 Brown-Flaming micropipette puller (Sutter Instrument Co., Novato, CA). The electrodes were back-filled with $1 \mathrm{~mol} / \mathrm{L} \mathrm{KCl}$ (resistance, 50-70 mol/ $\mathrm{L} \Omega$ ). The electrode was positioned by a micromanipulator (Narishige MO388; Narishige Scientific Instrument Lab, Toyko, Japan). Passive electrical events were measured with an Axoclamp 2A current-voltage amplifier (headstage HS-2 L, gain 0.1) connected to a Labmaster TL-1 DMA interface (Axon Instruments, Foster City, CA). The amplifier bridge circuit was balanced for each electrode before impalement, and capacitance was compensated for during injection of rectangular electrical current pulses ( $-.2 \mathrm{nA}, 7 \mathrm{~ms}$ ) through the microelectrode. After amplification and low-pass filtering $(3 \mathrm{kHz})$, the signal was digitized at a sample rate of $5 \mathrm{kHz}$ and stored on a computer using the pClamp 6.0.2 software (Axon Instruments).

\section{Morphometric Analyses}

To determine the cross-sectional area of the longitudinal and circular muscle layer of the jejunum, cross-sections were stained with $\mathrm{H} \& \mathrm{E}$. Images were captured using a Zeiss Axioscope (Zeiss, Göttingen, Germany) and a standard CCD camera (Stemmer Imaging, Puchheim, Germany), and analyzed with Leica QWin image analysis software (Leica Microsystems, Cambridge, UK). To determine the number of nuclei of the longitudinal and circular muscle layers of these sections, 2 opposite angular segments $\left(15^{\circ}\right)$ of the intestinal wall were selected and counted manually.

\section{Statistical Analyses}

Statistical significance was calculated by repeated-measures 1-way ANOVA followed by Bonferroni's multiple comparison test, or 2-tailed (paired) Student $t$ tests using Graphpad Prism software (version 4.0; GraphPad Software, Inc, San Diego, CA). Groups were considered significantly different when the $P$ value was less than .05 . Values are expressed as mean \pm standard error of the mean.

\section{Results}

\section{Mouse Model}

Smoothelin-A/B $\mathrm{B}^{-1-}$ mice were generated by removal of exons $18-20$ (Figure $1 A$ and $B$ ). These exons 

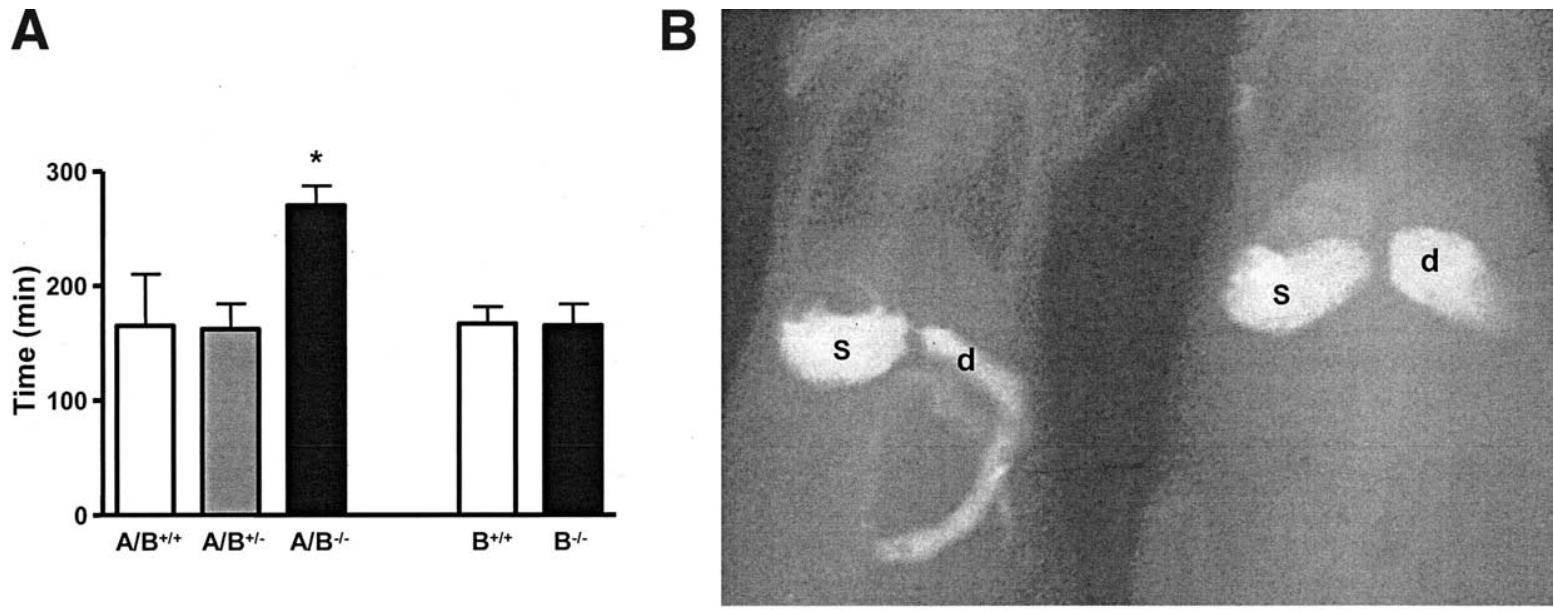

Smtn-A/B+/+

Smtn-A/B-

Figure 2. Whole-gut transit time of Smtn- $A / B^{+/+}$, Smtn- $A / B^{+/-}$, Smtn- $A / B^{-/-}$, Smtn- $B^{+/+}$, and Smtn- $B^{-/-}$mice. $(A)$ Whole-gut transit time of

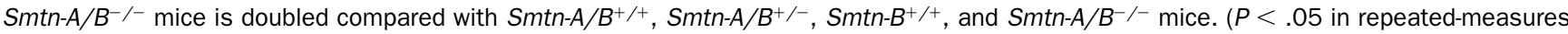
ANOVA followed by Bonferroni's multiple comparison tests.) (B) Representative picture of contrast radiography of $S m t n-A / B^{+/+}($left) and Smtn-A/B-1- (right). Picture was taken 20 minutes after injecting the barium sulfate solution into the stomach. S, stomachs; $d$, duodenum. Smtn-A/B-/- mice show a greatly dilated proximal duodenum and a slower progression of food transport into the jejunum.

code for the calponin homology domain that is involved in actin binding. ${ }^{11}$ The deletion resulted in smaller smoothelin transcripts with an intact reading frame, corresponding to variants with exons 16 or 17 spliced to exon 21 (Figure 1C). However, smoothelin protein could not be detected in smooth muscle tissues of $S m t n-A / B^{-1-}$ mice using an antibody against an epitope upstream of the deletion (Figure 1D), indicating that the targeting resulted in a null-mutation. Western blot analyses showed that $\alpha$-SMA was down-regulated in intestines of Smtn-A/B $B^{-1-}$ mice and smooth muscle myosin heavy chain concentration was similar (Figure $1 E$ ).

Smtn- $A / B^{-1-}$ pups were born at the expected Mendelian ratio $\left(S m t n-A / B^{+/+} 30 \% ; S m t n-A / B^{+/-} 46 \% ;\right.$ Smtn$\left.A / B^{-/-} 24 \%, \mathrm{n}=415\right)$. At birth, Smtn-A/B $B^{-/-}$mice had a size and weight comparable with their wild-type littermates, but their postnatal growth was retarded overtly and surviving animals reached only approximately $80 \%$ of normal body weight. In the $S m t n-A / B^{-1-}$ mice, a remarkable absence of visceral and subcutaneous fat was observed. About $50 \%$ of $S m t n-A / B^{-1-}$ mice died before weaning at 3 weeks of age (Figure $1 F$ ). Smtn- $A / B^{-1-}$ mice that developed into adulthood were infertile. In contrast, $S m t n-A / B^{+/-}$(and also $S m t n-B^{-1-}$ mice) had no overt abnormalities, were fertile, and had a normal life span.

\section{Whole-Gut Transit Time, Contractility, and Slow Wave Recordings}

Motility of the intestine was determined by functional assays. Carmine, a red dye, was injected into the stomach and stool was monitored. Despite a comparable length of the intestinal tract, the whole-gut transit time of $S m t n-A / B^{-/-}$mice was about twice as long as that of wild-type littermates (Figure $2 A$ ). Smtn- $B^{-/-}$mice showed no increase in whole-gut transit time (Figure $2 A)$. Contrast radiography after loading barium sulfate

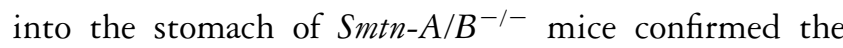

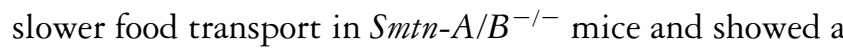
greatly dilated proximal duodenum (Figure $2 B$ ), which was confirmed by macroscopic and microscopic observations. Twenty minutes after injection of barium sulfate, hardly any barium had passed the duodenum in $S m t n-A$ / $B^{-/-}$mice, whereas in $S m t n-A / B^{+/+}$mice barium had proceeded several centimeters into the jejunum.

Isolated jejunal smooth muscle strips showed spontaneous spike activity in wild-type $S m t n-A / B^{-/-}$and $S m t n$ $B^{-/-}$mice. However, the amplitude and frequency of these spontaneous spikes were significantly lower in muscle strips of $S m t n-A / B^{-/-}$mice (amplitude: $S m t n-A / B^{+/+}$ $8.57 \pm 1.23$, Smtn-A/B $B^{-/-} 2.44 \pm .39$; frequency: Smtn$A / B^{+/+} 43.09 \pm 1.04$, Smtn- $A / B^{-/-} 31.30 \pm 1.70$ ). When subjected to several contractile agonists, the forces generated by these strips were in $5 m t n-A / B^{-1-}$ mice at least 4 times smaller than in control mice (Figure $3 A$ ). Electrical stimulation of excitatory enteric nerves showed at least a 5-fold stronger contraction in wild-type mice compared with $S m t n-A / B^{-1-}$ mice (Figure $3 A$ ). Also, receptor-independent contractions to $\mathrm{KCl}$ and receptordependent contractions to carbachol, prostaglandin $\mathrm{F} 2 \alpha$, substance $\mathrm{P}$, and serotonin were significantly lower for 
A

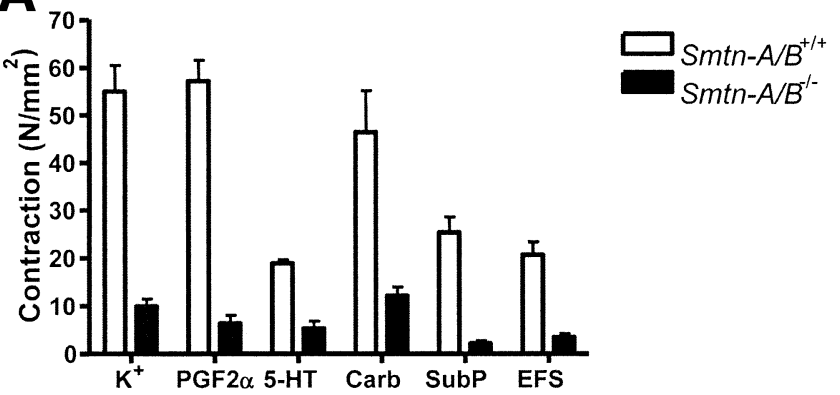

B

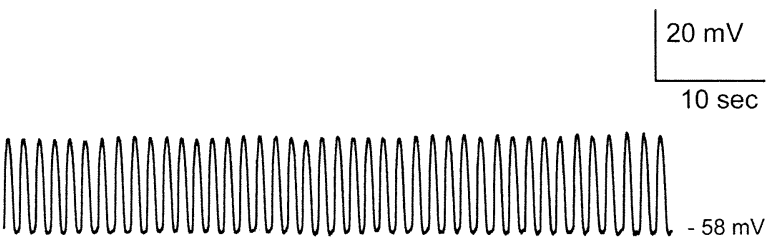

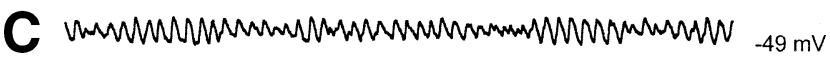

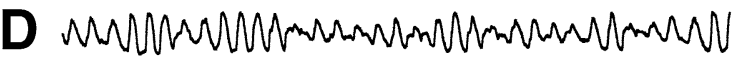

$-53 \mathrm{mV}$

Figure 3. Intestinal smooth muscle of $S m t n-A / B^{-/-}$mice shows reduced contractility and irregular slow wave patterns. $(A)$ Maximal contractile responses to $\mathrm{KCl}\left(\mathrm{K}^{+}\right)$, prostaglandin F2 $\alpha$ (PGF2 $\alpha$ ), serotonin (5-HT), carbachol (Carb), substance P (SubP), and electrical field stimulation are reduced strongly in jejunal longitudinal muscle strips

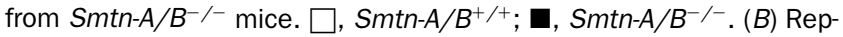
resentative tracing of a slow wave measured in a small intestinal smooth muscle cell of an Smtn-A/B $B^{+/+}$mouse. $(C, D)$ Two examples of slow waves measured in small intestinal smooth muscle cells of Smtn- $A / B^{-/-}$mice. The slow waves show lower and irregular amplitudes and a remarkable variability in frequency.

Smtn-A/B $B^{-/-}$mice (Figure $3 A$ ). In the same experimental set-up, contractility of jejunal strips of $S m+n-B^{-1-}$ mice was comparable with $S m t n-A / B^{+/+}$mice.

The slow waves measured in the SMCs of $S m t n-A / B^{-1-}$ mice were very irregular and variable, whereas in $S m t n$ $A / B^{+/+}$littermates, regular slow waves were observed in all cells tested (Figure $3 B-D$ ). The amplitude of the slow waves in $S m t n-A / B^{-1-}$ mice was significantly smaller (10 $\pm 1 \mathrm{mV})$ compared with $S m t n-A / B^{+/+}$mice $(24 \pm 1$ $\mathrm{mV}$ ), and the frequency of the slow waves was diminished significantly in $S m t n-A / B^{-/-}$vs $S m t n-A / B^{+/+}$mice $(33.7 \pm 2.0$ cycles $/ \mathrm{min}$ vs $39.8 \pm .6$ cycles $/ \mathrm{min})$. In addition, there was a much higher variability in frequency in $S m t n-A / B^{-1-}(0-53$ cycles $/ \mathrm{min})$ compared with $S m t n-A / B^{+/+}$littermates (35-46 cycles/min). In the same experimental set-up, the slow waves measured in the SMCs of $S m t n-B^{-1-}$ mice did not differ from wildtype mice.

\section{Pathology of the Intestine}

To ascertain whether the intestinal contractile dysfunction of $S m t n-A / B^{-1-}$ mice led to development of intestinal pathologies, we examined the morphology and histology of the digestive tract. No changes in the structure of the stomach were observed, although the structure of the intestine was compromised in $S m t n-A / B^{-1-}$ mice. The intestinal wall of $S m t n-A / B^{-1-}$ mice was stiff and fragile. The duodenum often was dilated (see also Figure $2 B$ ) and the mass of the jejunal smooth muscle was increased significantly compared with wild-type littermates (Table 1). The cross-sectional area of both longitudinal and circular muscle layers was approximately 4-fold greater in $S m t n-A / B^{-1-}$ mice than in wild-type mice (Figure $4 A$ and $B$ ), which could be attributed largely to SMC hypertrophy (Table 1). Nuclei and cytoplasm of the intestinal SMCs were larger in smoothelindeficient mice (Figures $4 C, D$, and 5). Extracellular matrix volume did not increase significantly as deduced from Sirius red staining and the distribution and appearance of the ICCs were normal (data not shown). Electron microscopy showed subtle differences in the ultrastructural organization of the intestinal SMCs. In Smtn-A/ $B^{-/-}$mice, the distribution of mitochondria and dense bodies appeared to be organized less strictly (Figure $5 \mathrm{~A}$ and $B$ ). In addition, the micropinocytotic vesicles that are characteristic of smooth muscle were common in $S m t n-A / B^{+/+}$mice but almost absent in $S m t n-A / B^{-/-}$ mice (Figure $5 C$ and $D$ ). Hypertrophy was less common and less extensive in the more distal part of the gut. Numerous diverticula were observed in all parts of the intestine with the exception of the cecum (Figure $4 E$ and $F)$. The diverticula were located predominantly on the mesenteric side. In $50 \%$ of the $S m t n-A / B^{-1-}$ mice, the diverticula already were present 24 hours after birth. The diverticula increased in number and size as the mice aged (Figure $4 F$ ). Inflammation of the diverticula and the mesentery was common, and perforations leading to sepsis and death were observed (Figure $4 G$ ). In addition, the intestinal villi in the affected areas were irregular and atrophic, which is probably a consequence of the dis-

Table 1. Smtn-A/B $B^{-/-}$Mice Show Jejunal Smooth Muscle Hypertrophy

\begin{tabular}{|c|c|c|c|}
\hline & $\begin{array}{c}\text { Smtn- } A / B^{+/+} \\
(n=5)\end{array}$ & $\begin{array}{c}\text { Smtn-A/B } B^{-/-} \\
(n=4)\end{array}$ & $\begin{array}{c}P \\
\text { value }\end{array}$ \\
\hline Intestinal $\mathrm{CSA}^{a}$ & $4.533 \pm 1.246$ & $7.582 \pm 1.780$ & $<.05$ \\
\hline Intestinal muscle $\mathrm{CSA}^{a}$ & $.376 \pm .130$ & $1.684 \pm .381$ & $<.001$ \\
\hline $\begin{array}{l}\text { Muscle area/intestinal } \\
\text { area }\end{array}$ & $9 \% \pm 3 \%$ & $23 \% \pm 3 \%$ & $<.001$ \\
\hline $\begin{array}{l}\text { Nuclei longitudinal } \\
\text { muscle } \\
\text { Nuclei circular muscle }\end{array}$ & $\begin{array}{l}71 \pm 12 \\
51+13\end{array}$ & $\begin{array}{l}81 \pm 20 \\
79+15\end{array}$ & $\begin{array}{r}\text { NS } \\
<05\end{array}$ \\
\hline
\end{tabular}

CSA, cross-sectional area; NS, not significant.

aValues shown in $\mathrm{mm}^{2}$.

${ }^{b}$ Number of nuclei per $10 \%$ of the intestinal circumference. 

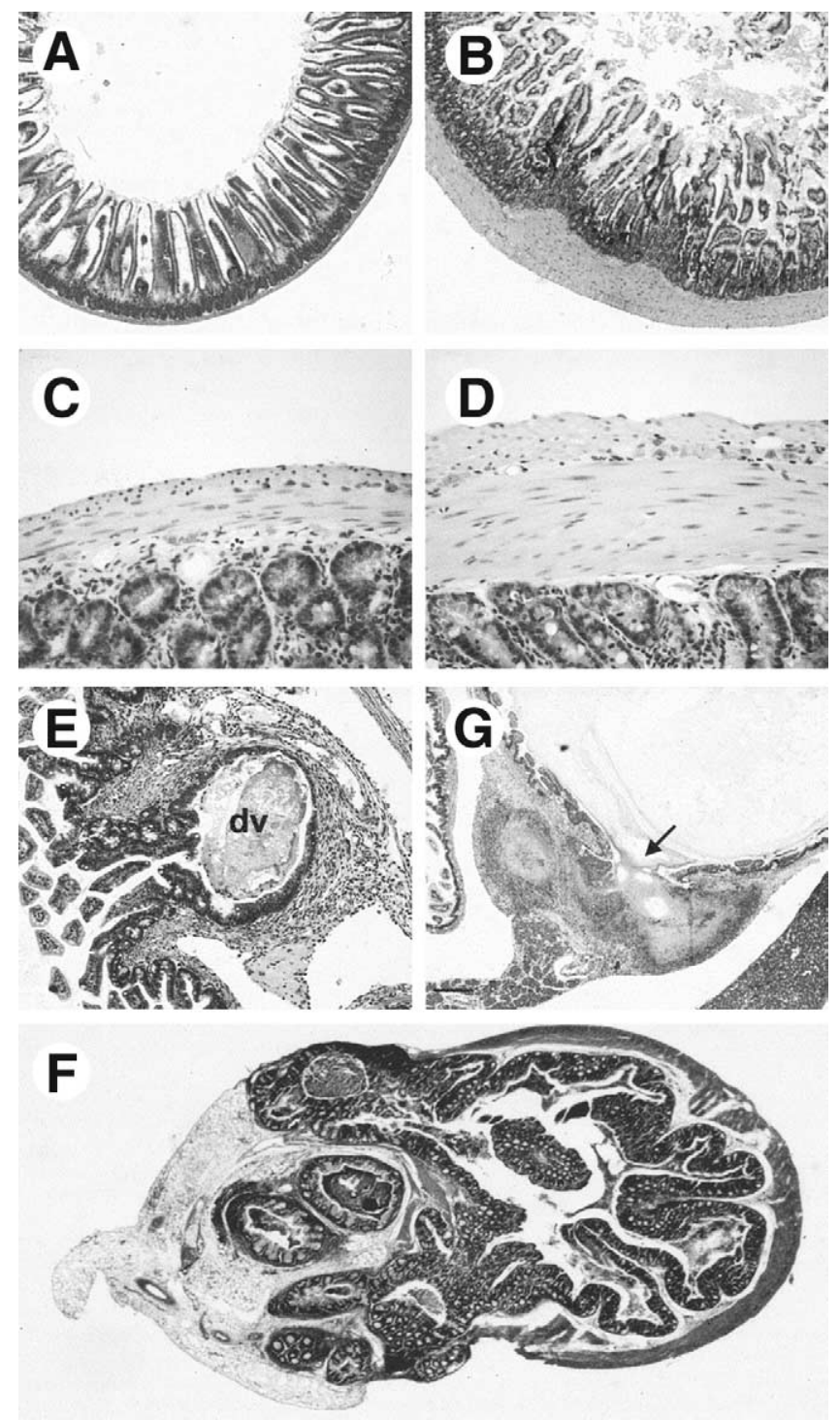

Figure 4. Smtn- $A / B^{-/-}$mice develop lethal pathologies in the digestive tract. Cross-sections of jejuna of 8-week-old $(A) S m t n-A / B^{+/+}$and (B) Smtn- $A / B^{-/-}$littermates showing irregular villi and profound hypertrophy of both circular and longitudinal smooth muscle layers in the Smtn-A/B $B^{-/-}$mouse. H\&E staining of jejuna of $(C)$ 8-week-old Smtn- $A / B^{+/+}$and $(D)$ Smtn- $A / B^{-/-}$littermates showing hypertrophy of

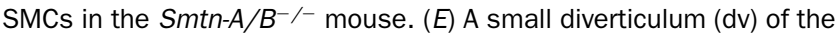
jejunum of a 10 -day-old $S m t n-A / B^{-1-}$ mouse still surrounded by smooth muscle. $(F)$ Cross-section of a colon of a 21-week-old Smtn$A / B^{-/-}$mouse showing typical severe diverticulosis. Little or no tunica muscularis is present on the side where the diverticula are observed, whereas the opposing side shows smooth muscle hypertrophy. $(G)$ Perforation (indicated by the arrow) of a colonic diverticulum of a 10-day-old Smtn-A/ $B^{-/-}$mouse. Leakage of intestinal material has caused the development of a large abscess in the abdominal cavity.

turbed motility and may be due to inflammation of the affected areas. The absence of fat deposition in Smtn-A/ $B^{-/-}$mice may be the consequence of diminished absorption as a result of the deteriorated structure of the villi. Inspection of the intestine of $S m t n-B^{-1-}$ mice did not show any abnormalities. Also, these mice had normal fat disposition, indicating sufficient food adsorption from the intestine. Furthermore, there are no morphologic changes in the intestinal vasculature of both $S m t n-A$ / $B^{-1-}$ and $S m t n-B^{-1-}$ mice at this age.

\section{Smoothelin Expression in Intestine of CIP Patients}

Because the phenotype of the $S m t n-A / B^{-1-}$ mice shares many aspects of the pathology seen in patients with CIP, we investigated the expression of smoothelin in intestines of those patients. In controls, smoothelin immunoreactivity stained all muscle layers uniformly, whereas, despite a normal morphology, lack of smoothelin was observed in the ileal circular muscle layer of a patient with CIP (Figure 6).

\section{Discussion}

Digestive motility is a highly coordinated process that enables mixing, propulsion, and absorption of food by the digestive tract. Disturbances in intestinal motility can occur at different levels as a result of aberrations in the enteric nervous system, ICCs, and/or the contractility of smooth muscle cells. They all lead to impaired gastrointestinal propulsion. When no obvious lesions are

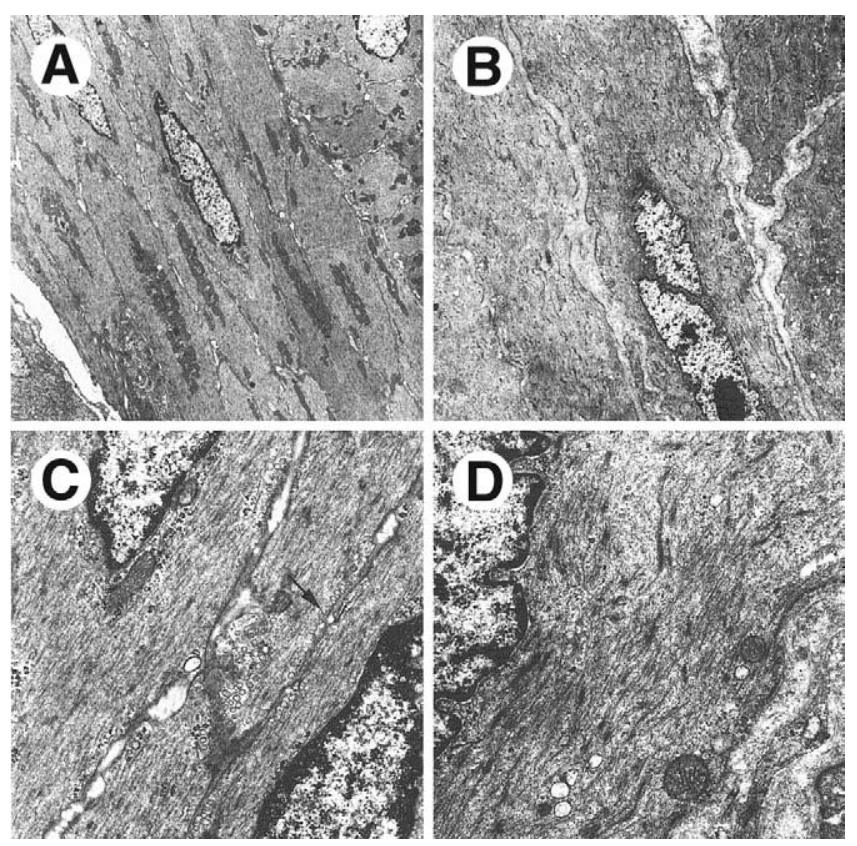

Figure 5. Differences in size and ultrastructure of intestinal SMCs in Smtn- $A / B^{-/-}$vs Smtn- $A / B^{+/+}$mice. Electron micrograph images of $(A, C)$ Smtn- $A / B^{+/+}$and $(B, D)$ Smtn- $A / B^{-/-}$mice show differences in cell size, thickness of the intercellular basal lamina, and the distribution of the mitochondria $(A, B ; 2200 \times)$. At larger magnification $(C, D$; $21,000 \times$ ) micropinocytotic vesicles (arrow) are apparent in Smtn-A/ $B^{+/+}$SMCs. 

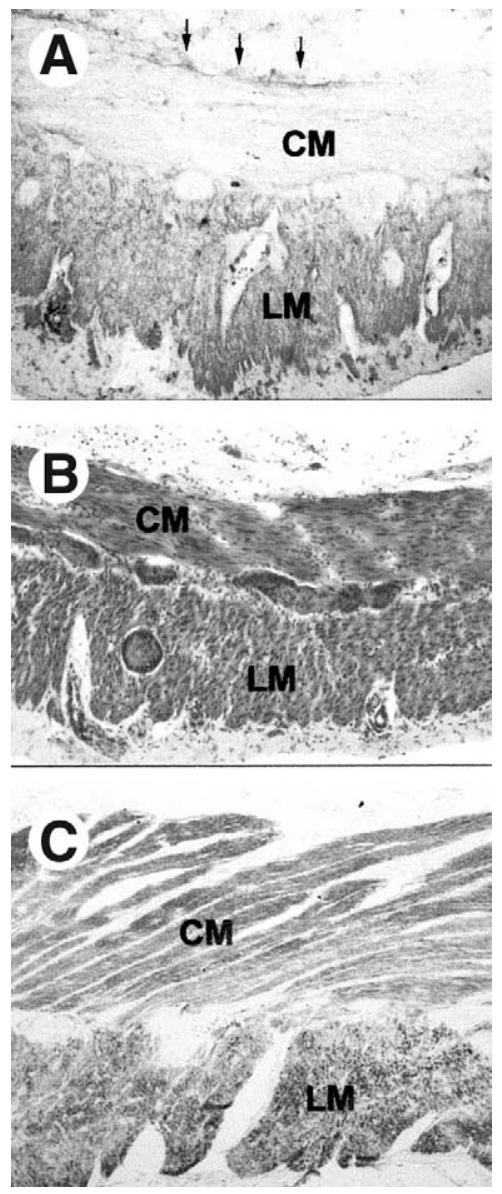

Figure 6. Absence of smoothelin in parts of the intestinal muscle layer of CIP patients. $(A)$ Immunohistochemical staining of ileum obtained from a patient with CIP shows the absence of smoothelin in the circular smooth muscle layer (CM), except for the innermost border as indicated by arrows. (B) H\&E staining of an adjacent section from the same specimen showing normal morphology. (C) Immunohistochemical staining of control ileum shows a homogeneous distribution of smoothelin in both circular (CM) and longitudinal (LM) smooth muscle layers.

obstructing intestinal transit, impaired food progress often is referred to as chronic intestinal pseudo-obstruction. ${ }^{19,20}$ Proper diagnosis and treatment of this rare and disabling disorder remain difficult, largely because the underlying pathology is understood poorly. Most attention has been paid to nervous system function in CIP, although smooth muscle myopathies appear to be responsible for the disease in approximately one third of the patients with congenital CIP, and in all cases of hollow visceral myopathy. ${ }^{21,22}$ For the neuronal-based CIP, a few relevant mouse models recently have become available. ${ }^{23}$ The myopathy-related CIP has obtained less attention and, to the best of our knowledge, no animal model is available. We describe a mouse model that displays clinical manifestations similar to CIP/hollow visceral myopathy, caused by a mutation in the smooth- elin gene. Moreover, we report on the absence of smoothelin in apparently unaffected intestine in CIP patients, providing evidence that smooth muscle dysfunction as a result of smoothelin deficiency might contribute to the development of this disease in humans.

Smoothelin-A is a marker protein for visceral SMCs. ${ }^{6,10}$ Analysis of intestinal muscle strips showed that inactivation of the smoothelin gene results in a decrease in contractile potential of intestinal SMCs. Smtn- $A / B^{-1-}$-derived muscle strips displayed a 4 times lower contractile force per unit muscle mass as control mice, independent of the used agonists and concentration. In contrast, contractility of intestinal smooth muscle strips of $S m t n-B^{-1-}$ mice was similar to wild-type mice (data not shown). These results show that smoothelin-A is the functional smoothelin isoform in intestinal tissues and that this protein is a key component in the contractile machinery of intestinal smooth muscle. The exact role of smoothelin-A in smooth muscle contraction remains to be elucidated. However, the reduced response to nonreceptor-mediated and receptor-mediated excitation indicates that smoothelin-A must be associated closely to the primary components of the contractile apparatus. In addition, the recently shown direct physical interaction of smoothelin with $\alpha$-SMA ${ }^{11}$ and the observed down-regulation of $\alpha$-SMA in intestines of $5 m t n$ $A / B^{-1-}$ mice indicate a cooperation of these 2 proteins. ${ }^{11}$

The observed disturbance of the slow waves in SMCs of $S m t n-A / B^{-1-}$ mice is intriguing and correlates well with the disturbed spontaneous activity of smooth muscle strips. Slow waves are generated by ICCs. ICCs do not contain smoothelin and both the number and distribution of these cells is normal in $S m t n-A / B^{-/-}$mice. Therefore, the loss of regularity must be caused by changes in the interaction between ICCs and SMCs or in the characteristics of SMCs (as found by electron microscopy), which interfere with proper communication between these cells. Alternatively, changes in the spatial structure of the smooth muscle layers may break-up the ICC network. SMCs then will receive noncoordinated signals from several ICCs. The latter is in line with the analysis of the $S m t n-A / B^{-1-}$ slow waves, which can be considered to be the result of 2 or more independent slow waves (according to Fourier analysis, data not shown). Regardless, the lack of smoothelin results in structural changes in the smooth muscle that interfere with the slow wave generation, which in turn diminishes the regulation of peristalsis.

The lack of smoothelin-A and consequent reduced contractility in $S m t n-A / B^{-/-}$mice has significant consequences for the intestinal performance. The retarded passage of the carmine bolus showed that whole-gut 
transit time was approximately doubled. This was confirmed by contrast radiography that showed the transit in the intestine of $S m t n-A / B^{-1-}$ mice to be much slower compared with $S m t n-A / B^{+/+}$littermates. Furthermore, the radiographs showed that the duodenum of $S m t n-A$ / $B^{-/-}$mice is dilated, which may be the result of chronic pseudo-obstruction in the small intestine. This deduction is supported by the hypertrophy of the smooth muscle in the intestinal wall, the deterioration of the intestinal mucosa and villi, and the numerous diverticula found in the intestine of $S m t n-A / B^{-/-}$mice. The 4-fold increased muscular cross-sectional area in $S m t n-A / B^{-/-}$ mice is likely to be an adaptive response to increased workload (as the result of the diminished contractility) of this pulsatively contracting muscle. Similar hypertrophy has been described for segments of the gut upstream of an obstruction ${ }^{24}$ and also has been documented extensively for other muscle types under increased workload such as the cardiac muscle. ${ }^{25-27}$ The diverticula, which already are found in very young mice and increase in number and size with age, point toward an increasing transverse pressure on the wall caused by the retarded food transport. The increased wall thickness decreases the flexibility of the intestinal wall. As a result, the pressure provokes herniation of mucosa and submucosa through the intestinal muscular wall at the mesenteric side, which is weaker because of the entering of mesenteric blood vessels and nerves. ${ }^{28}$ Thus, diverticulosis in Smtn$A / B^{-/-}$mice most likely results from a loss of intestinal SMC contractile performance in combination with increased wall rigidity. Smtn-A/B $B^{-1-}$ mice with sick and apathetic behavior were shown to have extensive diverticulosis. Human intestinal diverticulosis is a rather common disease, affecting $30 \%-50 \%$ of people over the age of 60 and causing strong and recurrent abdominal pain. ${ }^{29}$ The premature death of $S m t n-A / B^{-/-}$mice is most likely due to intestinal perforation or starvation caused by intestinal dysfunction and diverticulosis.

The present study focused on intestinal problems as a consequence of interruption of the smoothelin gene because the intestine always was affected. Investigations of other parts of the gastrointestinal tract (esophagus, stomach) did not show aberrations. However, reduced function was found for other organs such as the urogenital system. In some animals, these pathologies occurred simultaneously, in other animals 1 or 2 of the organ systems were affected. We have no explanation for the variety in onset and type of pathology or for the fact that in the group of $S m t n-A / B^{-/-}$mice with intestinal malfunction some mice died on the first day after birth whereas others lived for months. However, similar variations are found in CIP and hollow visceral myopathy.
Back-crossing on other mouse strains had no effect on this variation, which makes genomic diversity as the cause of the observed differences less likely. The physiologic part of this study was performed with mice that survived for more than 5 weeks. As can be deduced from Figure $1 F$, this was a small group and therefore the results were obtained from mice that had a late onset of intestinal dysfunction.

In conclusion, we have shown that smoothelin-A deficiency causes a major decrease in the contractile performance of intestinal smooth muscle. By showing that the reduction in contractility occurs independently of the signal transduction pathway activated, we have identified smoothelin-A as a structural protein that is crucial for normal intestinal smooth muscle contractility. Mutations in the Smtn gene or alterations in smoothelin-A levels may play an important role in the development of smooth muscle myopathies such as CIP or hollow visceral myopathy and intestinal diverticulosis.

\section{References}

1. Kunze WA, Furness JB. The enteric nervous system and regulation of intestinal motility. Annu Rev Physiol 1999;61:117-142.

2. Herzog W, Ait-Haddou R. Considerations on muscle contraction. J Electromyogr Kinesiol 2002;12:425-433.

3. Gordon AM, Homsher E, Regnier M. Regulation of contraction in striated muscle. Physiol Rev 2000;80:853-924.

4. Owens GK, Kumar MS, Wamhoff BR. Molecular regulation of vascular smooth muscle cell differentiation in development and disease. Physiol Rev 2004;84:767-801.

5. Szymanski PT. Calponin ( $\mathrm{CaP}$ ) as a latch-bridge protein-a new concept in regulation of contractility in smooth muscles. J Muscle Res Cell Motil 2004;25:7-19.

6. van Eys GJ, Voller MC, Timmer ED, Wehrens XH, Small JV, Schalken JA, Ramaekers FC, van der Loop FT. Smoothelin expression characteristics: development of a smooth muscle cell in vitro system and identification of a vascular variant. Cell Struct Funct 1997;22:65-72.

7. Rensen S, Thijssen V, De Vries C, Doevendans P, DeteraWadleigh S, Van Eys G. Expression of the smoothelin gene is mediated by alternative promoters. Cardiovasc Res 2002;55: 850-863.

8. Christen T, Verin V, Bochaton-Piallat ML, Popowski Y, Ramaekers F, Debruyne P, Camenzind E, van Eys G, Gabbiani G. Mechanisms of neointima formation and remodeling in the porcine coronary artery. Circulation 2001;103:882-888.

9. van der Loop FT, Gabbiani G, Kohnen G, Ramaekers FC, van Eys GJ. Differentiation of smooth muscle cells in human blood vessels as defined by smoothelin, a novel marker for the contractile phenotype. Arterioscler Thromb Vasc Biol 1997;17:665-671.

10. van der Loop FT, Schaart G, Timmer ED, Ramaekers FC, van Eys GJ. Smoothelin, a novel cytoskeletal protein specific for smooth muscle cells. J Cell Biol 1996;134:401-411.

11. Niessen P, Clement S, Fontao L, Chaponnier C, Teunissen B, Rensen S, van Eys G, Gabbiani G. Biochemical evidence for interaction between smoothelin and filamentous actin. Exp Cell Res 2004;292:170-178.

12. van der Heijden OW, Essers YP, Fazzi G, Peeters LL, De Mey JG, van Eys GJ. Uterine artery remodeling and reproductive performance are impaired in endothelial nitric oxide synthase-deficient mice. Biol Reprod 2005;72:1161-1168. 
13. Rumessen JJ, Vanderwinden JM. Interstitial cells in the musculature of the gastrointestinal tract: Cajal and beyond. Int Rev Cytol 2003;229:115-208.

14. Vanderwinden JM, Rumessen JJ, Liu H, Descamps D, De Laet MH, Vanderhaeghen JJ. Interstitial cells of Cajal in human colon and in Hirschsprung's disease. Gastroenterology 1996;111:901-910.

15. van der Zee R, Welling GW. A simple method to determine the transit time in mice. Z Versuchstierkd 1983;25:233-237.

16. Pelckmans PA, Boeckxstaens GE, Van Maercke YM, Herman AG, Verbeuren TJ. Acetylcholine is an indirect inhibitory transmitter in the canine ileocolonic junction. Eur J Pharmacol 1989;170:235242.

17. Kunze WA, Bertrand PP, Furness JB, Bornstein JC. Influence of the mucosa on the excitability of myenteric neurons. Neuroscience 1997;76:619-634.

18. Brookes SJ, Ewart WR, Wingate DL. Intracellular recordings from myenteric neurones in the human colon. J Physiol 1987;390: 305-318.

19. Smith VV, Milla PJ. Histological phenotypes of enteric smooth muscle disease causing functional intestinal obstruction in childhood. Histopathology 1997;31:112-122.

20. De Giorgio R, Sarnelli G, Corinaldesi R, Stanghellini V. Advances in our understanding of the pathology of chronic intestinal pseudo-obstruction. Gut 2004;53:1549-1552.

21. Rodrigues CA, Shepherd NA, Lennard-Jones JE, Hawley PR, Thompson $\mathrm{HH}$. Familial visceral myopathy: a family with at least six involved members. Gut 1989;30:1285-1292.

22. Hyman PE, Bursch B, Sood M, Schwankovsky L, Cocjin J, Zeltzer LK. Visceral pain-associated disability syndrome: a descriptive analysis. J Pediatr Gastroenterol Nutr 2002;35:663-668.

23. Kapur RP. Neuropathology of paediatric chronic intestinal pseudo-obstruction and related animal models. J Pathol 2001;194: 277-288.

24. Geuna S, Cardillo S, Giacobini-Robecchi MG. Smooth muscle cell hypertrophy and hyperplasia in the partially obstructed gut of the rat: a quantitative evaluation. Acta Anat (Basel) 1998; 163:69-74.

25. Sadoshima J, Izumo S. The cellular and molecular response of cardiac myocytes to mechanical stress. Annu Rev Physiol 1997; 59:551-571.

26. Bell D, Kelso EJ, Argent CC, Lee GR, Allen AR, McDermott BJ. Temporal characteristics of cardiomyocyte hypertrophy in the spontaneously hypertensive rat. Cardiovasc Pathol 2004;13:7178.

27. Anversa P, Ricci R, Olivetti G. Quantitative structural analysis of the myocardium during physiologic growth and induced cardiac hypertrophy: a review. J Am Coll Cardiol 1986;7:1140-1149.

28. West $A B$, Losada M. The pathology of diverticulosis coli. J Clin Gastroenterol 2004;38(Suppl):S11-S16.

29. Stollman N, Raskin JB. Diverticular disease of the colon. Lancet 2004;363:631-639.

Received March 23, 2005. Accepted August 10, 2005.

Address requests for reprints to: Guillaume van Eys, PhD, Department of Genetics and Cell Biology, University of Maastricht, PO Box 616, 6200 MD Maastricht, The Netherlands. e-mail: G.vaneys@ gen.unimaas.nl; fax: (31) 433884574.

P.N., S.R., and J.V.D. contributed equally to this article.

Supported by grants from the Netherlands Heart Foundation (97.167), Stichting De Gelderfonds, Stichting Simonsfonds, the Netherlands Organization for Scientific Research (NWO), Interuniversity Pole of Attraction (grant P5/20) of the Belgian Government, the Borne Bunge Foundation, the National Fund for Scientific Research (Belgium), the Foundation Médicale Reine Elisabeth, and the Deutsche Forschungsgemeinschaft (DFG We2366/3-1).

The authors thank Alfons Kroese, Roy Vliegen, Jean-Pierre Timmermans, and Pierre-Paul van Bogaert for their collaboration. Expert technical assistance by our colleagues from the animal facility and by Hans Duimel, J. Ramesh Babu, Alexandra Oldenhof, and Diane Fens is gratefully acknowledged. The support of Be Wieringa in the initial phase of this study is appreciated. 